\title{
Physicochemical Properties of Octane Isomers in View of the Structural Numbers
}

\author{
Anton Perdih \\ Faculty of Chemistry and Chemical Technology, University of Ljubljana (retired) \\ Večna pot 113, 1000 Ljubljana, Slovenia \\ *Corresponding author: E-mail: a.perdih@gmail.com
}

Received: 06-07-2020

\begin{abstract}
The structural features of octane isomers were quantified with help of the Structural Numbers. A Mutually Optimized Contribution of the Structural Numbers $\left(\mathrm{MOC}_{\mathrm{SN}}\right.$ ) was used to calculate which parts of information regarding branching contribute the tested Structural Numbers. Besides the known Structural Numbers, two Asymmetry Numbers were developed in order to quantify the asymmetry of the octane isomers, one regarding the asymmetry along the main chain of the molecule and the other one regarding the asymmetry perpendicular to the main chain of the molecule. Their correlation to the values of 29 tested physicochemical properties of octanes was low, $|R|<0.6$. After optimization of the Mutually Optimized Contribution of the Structural Numbers, the Information Content of the Mutually Optimized Contribution of the Structural Numbers ranged from $34.3 \%$ to $89.0 \%$ of the information contained in the physicochemical properties. The Structural Numbers enable the first step of the structural interpretation of physicochemical properties of octane isomers. In 17 out of 29 cases the most of information contained in the physicochemical properties is presented among the Structural Numbers by the Number of Branches, in 8 cases by the Peripheral Number, in 3 cases by an Asymmetry Number and in 1 case by the Distance Number.
\end{abstract}

Keywords: Octanes; asymmetry number; distance number; number of branches; peripheral number; size of the largest branch; structural interpretation.

\section{Introduction}

In order to estimate the unknown values of the physicochemical properties (PCP) of alkanes, Wiener ${ }^{1}$ started the development of the numerical measures of their structure, later named the topological indices. ${ }^{2,3}$ In the structure of alkanes, the branching of their molecules is obvious. Branching of molecules is easily apprehended. It comprises several structural variables, for example the number of branches, their valencies, their distances apart, their distance from the graph center, the lengths of branches, etc. ${ }^{4}$ However, any definition of branching must rest on an intuitive basis. ${ }^{5}$ Bonchev and Trinajstić ${ }^{6}$ presented several rules representing branching. Later, these rules were improved. ${ }^{7}$ In that time, branching was attempted to be defined using few topological indices, ${ }^{8}$ either the Wiener ${ }^{1}$ index or the largest eigenvalue of the adjacency matrix. ${ }^{9,10}$ As a new basis for the definition of branching the largest eigenvalue of the path matrix was provided. ${ }^{8}$ There was also stressed the dilemma, whether a branching index should correlate well with physico- chemical properties of alkanes or should it serve its own purpose to index branching regardless the correlation with the physicochemical properties. The attention was focused on the definition of branching, rather than to the application of it. ${ }^{8}$ Randić and Wilkins ${ }^{11}$ demonstrated the ordering of structures based on path indices. There have been presented also the intuitively derived sequences of octanes of increasing branching as well as some topological indices, which order the octane isomers into such sequences. Topological indices, which order the octane isomers into sequences of increasing branching, were, however, not good indices of the physicochemical properties of octanes. ${ }^{12}$

Later on, ${ }^{13}$ based on physicochemical properties of octanes, which correlated to $R>0.9$ to an intuitively derived sequence of octanes of increasing branching, ${ }^{12}$ there was introduced the concept and the values of Branching Degrees of octane isomers. There were defined some Structural Numbers as well. Besides the previously known Number of Branches $\left(\mathrm{N}_{\mathrm{br}}\right)$, also the values of the Peripheral Number $\left(\mathrm{N}_{\mathrm{per}}\right)$, the Distance Number $\left(\mathrm{N}_{\mathrm{d}}\right)$, as well as the 
Size of the Largest Branch $\left(\mathrm{L}_{\mathrm{br}}\right)$ were defined and their correlation to a number of physicochemical properties of octanes was determined. ${ }^{13}$

In a previous trial, it has been noticed that the symmetry of molecules has some importance in the Principal Component Analysis of physicochemical properties of alkanes, where the axis PC4 separates first of all the elongated and flat molecules from the spherical ones and among the former ones the symmetric from the asymmetric ones. However, the variance contained in the axis PC4 was low ( $3 \%$ or less). In the case of tested topological indices, it was hardly noticeable. ${ }^{14}$

To test the importance of symmetry of octanes regarding their physicochemical properties (PCP) in a different way, in present paper two measures of symmetry of octane molecules, i.e two Asymmetry Numbers were developed. They were tested alone as well as in combination with other Structural Numbers. The Structural Numbers are not another type of topological indices. They are the quantification of the structural features of alkanes. In present paper is performed the test, which part of information contained in the physicochemical properties of octanes can be explained using the mutually optimized contribution of the Structural Numbers. For other groups of alkanes, the Structural Numbers of them are to be derived and used using the approach described below.

\section{Notation and Physicochemical Properties of Octane Isomers}

Notations and physicochemical properties of octane isomers were presented in a previous paper. ${ }^{15}$

\section{Calculations}

The software for statistics calculations included in the program package MS Excel was used.

The definitions of the Structural Numbers are as follows. ${ }^{13}$ The Peripheral Number $\mathrm{N}_{\text {per }}$ was defined as $\mathrm{N}_{\text {per }}=$ $\Sigma \mathrm{d}_{\text {sy }}$, where $\mathrm{d}_{\mathrm{sy}}$ is the distance of a branch from the axis of symmetry of the main chain of the molecular graph. The Distance Number $\mathrm{N}_{\mathrm{d}}$ was defined as the distance between two branches. The Size of the Largest Branch $\mathrm{L}_{\mathrm{br}}$ was equal to the number of vertices in the branch.

Here are defined as a new Structural Number two types of the Asymmetry Number: $\mathrm{N}_{\mathrm{asym}} \leftrightarrow$ and $\mathrm{N}_{\mathrm{asym} \perp}$.
As measures of the goodness of correlation were used the correlation coefficient, $R$, the standard error, $S$, and the information content regarding branching, ${ }^{15}$ IC.

\section{Results}

The definitions of the Asymmetry Numbers $\mathrm{N}_{\text {asym }} \leftrightarrow$ and $\mathrm{N}_{\text {asym } \perp}$ are as follows:

$\mathrm{N}_{\text {asym } \leftrightarrow}$ is the difference of distances of branches from the symmetry axis of the main chain of the octane molecule.

$\mathrm{N}_{\text {asym } \perp}$ is the difference of the distances of vertices in branches perpendicular to the main chain of the octane molecule.

The Asymmetry Numbers are the inverse measures of the symmetry of molecules. For symmetrical molecules any $\mathrm{N}_{\text {asym }}=0$, whereas for non-symmetrical ones any $\mathrm{N}_{\text {asym }}>0$. Their values are presented in Table 1 .

The Asymmetry Numbers were correlated to the physicochemical properties of octanes. At $\mathrm{N}_{\mathrm{asym} \leftrightarrow}$, the absolute values of the correlation coefficient, $|R|$, range from 0.004 to 0.419 , whereas at $\mathrm{N}_{\text {asym } \perp}$ the range is $0.016<|R|<$ 0.602 . This is in line with an earlier observation ${ }^{14}$ that on the Principal Component Analysis the variance contained in the axis PC4, which separates the symmetric molecules from the asymmetric ones, was low.

The highest correlations with the Asymmetry Numbers were observed at the physicochemical properties Solubility Parameter, Cohesive Energy Density, the Antoine parameter B and Surface Tension. These are the physicochemical properties of low correlation with other Structural Numbers. ${ }^{15}$ They correlate negatively with the Asymmetry Numbers indicating that their values are higher among the more symmetrical molecules of octanes.

Table 2. Correlation of the Asymmetry Numbers with the number of branches $\left(\mathrm{N}_{\mathrm{br}}\right)$, with the peripheral number $\left(\mathrm{N}_{\mathrm{per}}\right)$, with the distance number $\left(\mathrm{N}_{\mathrm{d}}\right)$, with the size of the largest branch $\left(\mathrm{L}_{\mathrm{br}}\right)$, as well as with the branching degrees of octane isomers $\left(\mathrm{Br}\right.$. Deg. $\left.\mathrm{V}_{\mathrm{L}}\right)$.

\begin{tabular}{lcc}
\hline Struct. No. & $\boldsymbol{R} \mathbf{N}_{\text {asym } \leftrightarrow}$ & $\boldsymbol{R} \mathbf{N}_{\text {asym } \perp}$ \\
\hline $\mathrm{N}_{\text {per }}$ & 0.451 & 0.166 \\
$\mathrm{~L}_{\mathrm{br}}$ & 0.031 & 0.385 \\
$\mathrm{~N}_{\mathrm{d}}$ & -0.296 & -0.113 \\
$\mathrm{~N}_{\mathrm{br}}$ & 0.000 & 0.067 \\
Br. Deg. $\mathrm{V}_{\mathrm{L}}$ & -0.017 & 0.087 \\
\hline
\end{tabular}

Br. Deg. $V_{L}-$ Branching degrees derived from the values of the index $\mathrm{V}_{\mathrm{L}}(-0.126,-0.139,-0.270) .{ }^{11}$

Table 1. Asymmetry Numbers of octane isomers.

Oct 2M7 3M7 4M7 3Et6 25M6 24M6 23M6 34M6 3Et2M5 22M6 33M6 3Et3M5 234M5 224M5 223M5 233M5 2233M4

\begin{tabular}{lllllllllllllllllll}
\hline $\mathrm{N}_{\text {asym } \perp}$ & 0 & 2 & 1 & 0 & 1 & 0 & 1 & 2 & 0 & 1 & 3 & 1 & 0 & 0 & 1 & 2 & 1 & 0 \\
$\mathrm{~N}_{\text {asym } \leftrightarrow}$ & 1 & 1 & 1 & 2 & 0 & 2 & 0 & 0 & 2 & 2 & 2 & 1 & 1 & 3 & 1 & 1 & 0 \\
\hline
\end{tabular}


The correlation of the Asymmetry Numbers with other Structural Numbers are presented in Table 2.

In present stage, there is defined also the Mutually Optimized Contribution of the Structural Numbers $\left(\mathrm{MOC}_{\mathrm{SN}}\right.$ ) containing the Structural Numbers $\mathrm{N}_{\mathrm{br}} \mathrm{N}_{\mathrm{per}} \mathrm{N}_{\mathrm{d}}$, $\mathrm{L}_{\text {br }}, \mathrm{N}_{\text {asym } \leftrightarrow}$, and $\mathrm{N}_{\text {asym } \perp \text {. }}$.

$\mathrm{MOC}_{\mathrm{SN}}=\mathrm{k}_{\mathrm{Nbr}} \times \mathrm{N}_{\mathrm{br}}+\mathrm{k}_{\mathrm{Nper}} \times \mathrm{N}_{\mathrm{per}}+\mathrm{k}_{\mathrm{Nd}} \times \mathrm{N}_{\mathrm{d}}+\mathrm{k}_{\mathrm{Lbr}} \times \mathrm{L}_{\mathrm{br}}$ $+\mathrm{k}_{\leftrightarrow} \times \mathrm{N}_{\text {asym } \leftrightarrow}+\mathrm{k}_{\perp} \times \mathrm{N}_{\text {asym } \perp}$

In $\mathrm{MOC}_{\mathrm{SN}}$ there is $\Sigma\left|\mathrm{k}_{\mathrm{Ni}}\right|=1$.

$\mathrm{MOC}_{\mathrm{SN}}$ was optimized to each physicochemical property of octanes separately.

The results are presented in Table 3 for the case of the tested physicochemical properties of octanes.

The positive value of a coefficient $\mathrm{k}_{\mathrm{Ni}}$ means that with increasing value of $\mathrm{N}_{\mathrm{i}}$ the value of that physicochemical property increases, whereas the negative value of a coefficient $\mathrm{k}_{\mathrm{Ni}}$ indicates the decrease.

The optimized $\mathrm{MOC}_{\mathrm{SN}}$ represents $89.0 \%$ of the information regarding branching of octanes contained in $\mathrm{Tc} / \mathrm{Pc}$, whereas it represents only $34.3 \%$ of the information regarding branching of octanes contained in the critical property ac.
The highest correlation with the optimized $\mathrm{MOC}_{\mathrm{SN}}$ have the physicochemical properties $(R=0.994, I C \sim 90)>$ $\mathrm{Tc} / \mathrm{Pc}>\mathrm{Tc}^{2} / \mathrm{Pc}>\mathrm{RON}>(R=0.990)>\mathrm{BON}>\mathrm{BP} / \mathrm{Tc}>\mathrm{Pc}$ $>\omega>(R=0.980, I C \sim 80)$.

The lowest correlation have the critical properties $(R=0.86, \mathrm{IC} \sim 50)>\mathrm{Vc}>\mathrm{dc}>\mathrm{Zc}>\alpha \mathrm{c}>(R=0.75, \mathrm{IC} \sim$ $30)$.

In slightly more than half of tested cases, i.e. in 16 out of 29 cases, $\left|k_{\perp}\right|>\left|k_{\leftrightarrow}\right|$ indicating that the asymmetry perpendicular to the main chain has a higher influence on the value of a physicochemical property of octanes then the asymmetry along the main chain.

This can be observed for Solubility Parameter, the Cohesive Energy Density, the Antoine constant B and $\Delta \mathrm{Hv}$. In other cases, especially at the critical properties ac, $\mathrm{dc}$ and $\mathrm{Vc}$ the reverse is true.

As estimated by the absolute value of the factor $\left|\mathrm{k}_{\mathrm{Ni}}\right|$, the contribution of $\mathrm{N}_{\mathrm{br}}$ is higher than the contribution of other structural features at $\left(\left|\mathrm{k}_{\mathrm{Nbr}}\right|=0.7\right)>\omega>\mathrm{RON}>$ $\mathrm{BON}>\mathrm{Tc}^{2} / \mathrm{Pc}>\mathrm{C}>\left(\left|\mathrm{k}_{\mathrm{Nbr}}\right|=0.6\right)>\mathrm{MON}>\mathrm{BP} / \mathrm{Tc}>\mathrm{Tc} / \mathrm{Pc}$ $>\mathrm{R}^{2}>\Delta \mathrm{Hv}>\left(\left|\mathrm{k}_{\mathrm{Nbr}}\right|=0.5\right)>\mathrm{S}>\mathrm{Pc}>\left(\left|\mathrm{k}_{\mathrm{Nbr}}\right|=0.4\right)>\mathrm{d}>$ $\mathrm{Vm}>\left(\left|\mathrm{k}_{\mathrm{Nbr}}\right|=0.3\right)>\mathrm{n}_{\mathrm{D}}>\mathrm{A}>\mathrm{Zc}>\left(\left|\mathrm{k}_{\mathrm{Nbr}}\right|=0.25\right)$.

Table 3. Results of the optimization of the correlation between the $\mathrm{MOC}_{\mathrm{SN}}$ and the values of tested physicochemical properties of octanes sorted by the Information Content regarding branching, ${ }^{15}$ IC.

\begin{tabular}{|c|c|c|c|c|c|c|c|c|c|}
\hline PCP & $\mathbf{k}_{\mathrm{Nbr}}$ & $\mathbf{k}_{\mathrm{Nper}}$ & $\mathbf{k}_{\mathrm{Nd}}$ & $\mathbf{k}_{\text {Lbr }}$ & $\mathbf{k}_{\leftrightarrow}$ & $\mathbf{k}_{\perp}$ & $R$ & $S$ & IC $(\%)$ \\
\hline $\mathrm{Tc} / \mathrm{Pc}$ & -0.541 & 0.231 & 0.003 & -0.158 & -0.043 & 0.024 & 0.9939 & 0.093 & 89.0 \\
\hline $\mathrm{Tc}^{2} / \mathrm{Pc}$ & -0.635 & 0.088 & -0.031 & -0.138 & -0.007 & -0.101 & 0.9921 & 55.791 & 87.4 \\
\hline RON & 0.694 & -0.079 & -0.006 & 0.150 & 0.059 & -0.012 & 0.9916 & 4.753 & 87.1 \\
\hline BON & 0.640 & -0.090 & 0.023 & 0.171 & 0.052 & 0.024 & 0.9896 & 4.944 & 85.6 \\
\hline $\mathrm{BP} / \mathrm{Tc}$ & -0.596 & 0.201 & 0.066 & -0.082 & -0.028 & 0.027 & 0.9870 & 0.001 & 83.9 \\
\hline Pc & 0.429 & -0.263 & -0.027 & 0.144 & 0.049 & -0.088 & 0.9858 & 0.208 & 83.2 \\
\hline$\omega$ & -0.698 & 0.152 & 0.075 & -0.031 & -0.010 & -0.034 & 0.9821 & 0.007 & 81.2 \\
\hline $\mathrm{MON}$ & 0.598 & -0.066 & -0.017 & 0.262 & 0.048 & 0.009 & 0.9786 & 6.945 & 79.4 \\
\hline $\mathrm{d}$ & 0.305 & -0.256 & -0.044 & 0.192 & 0.053 & -0.150 & 0.9634 & 0.003 & 73.2 \\
\hline $\mathrm{Vm}$ & -0.302 & 0.257 & 0.045 & -0.191 & -0.055 & 0.150 & 0.9627 & 0.716 & 72.9 \\
\hline $\mathrm{n}_{\mathrm{D}}$ & 0.288 & -0.225 & -0.086 & 0.192 & 0.043 & -0.166 & 0.9616 & 0.001 & 72.5 \\
\hline$\Delta \mathrm{Hv}$ & -0.507 & -0.086 & -0.034 & 0.124 & 0.024 & -0.225 & 0.9566 & 0.064 & 70.9 \\
\hline $\mathrm{BP}$ & -0.240 & -0.305 & -0.011 & 0.109 & 0.086 & -0.249 & 0.9554 & 1.862 & 70.5 \\
\hline ST & 0.113 & -0.343 & -0.062 & 0.199 & 0.046 & -0.237 & 0.9552 & 0.269 & 70.4 \\
\hline Tc & 0.197 & -0.350 & -0.048 & 0.126 & 0.081 & -0.198 & 0.9493 & 2.751 & 68.6 \\
\hline $\mathrm{C}$ & 0.608 & 0.018 & -0.180 & 0.033 & -0.119 & 0.042 & 0.9488 & 1.300 & 68.4 \\
\hline S & -0.498 & -0.075 & 0.200 & -0.067 & 0.106 & 0.054 & 0.9440 & 1.535 & 67.0 \\
\hline $\mathrm{R}^{2}$ & -0.513 & 0.073 & -0.127 & -0.222 & 0.019 & -0.046 & 0.9402 & 0.064 & 65.9 \\
\hline CED & -0.072 & -0.247 & -0.098 & 0.252 & 0.033 & -0.298 & 0.9398 & 0.001 & 65.8 \\
\hline Sol.par. & -0.071 & -0.246 & -0.098 & 0.253 & 0.033 & -0.299 & 0.9392 & 0.001 & 65.7 \\
\hline $\mathrm{B}$ & -0.008 & -0.218 & -0.221 & 0.178 & -0.068 & -0.307 & 0.9371 & 9.183 & 65.1 \\
\hline MR & -0.278 & 0.299 & -0.083 & -0.163 & -0.090 & 0.087 & 0.9028 & 0.085 & 60.2 \\
\hline$\Delta \mathrm{Hf}^{\circ} \mathrm{g}$ & 0.195 & 0.343 & -0.148 & -0.107 & -0.124 & 0.083 & 0.9055 & 0.548 & 57.6 \\
\hline A & -0.260 & 0.101 & -0.189 & 0.120 & -0.145 & -0.185 & 0.9041 & 0.013 & 57.2 \\
\hline $\log V P$ & 0.141 & -0.101 & 0.261 & -0.170 & 0.115 & 0.212 & 0.8840 & 0.083 & 53.3 \\
\hline Vc & -0.264 & 0.284 & -0.085 & -0.157 & -0.159 & -0.051 & 0.8551 & 0.008 & 48.2 \\
\hline $\mathrm{dc}$ & 0.262 & -0.287 & 0.085 & 0.152 & 0.163 & 0.051 & 0.8460 & 0.005 & 46.7 \\
\hline $\mathrm{Zc}$ & 0.257 & 0.189 & -0.170 & -0.051 & -0.202 & -0.131 & 0.7697 & 0.005 & 36.2 \\
\hline$\alpha c$ & -0.243 & 0.250 & -0.219 & -0.056 & -0.184 & -0.048 & 0.7540 & 0.095 & 34.3 \\
\hline
\end{tabular}


The contribution of $\mathrm{N}_{\text {per }}$ is higher than the contribution of other structural features at $\left(\left|\mathrm{k}_{\mathrm{Nper}}\right|=0.4\right)>\mathrm{Tc}>$ $\Delta \mathrm{Hf}^{\circ} \mathrm{g}>\mathrm{ST}>\mathrm{BP}>\left(\left|\mathrm{k}_{\mathrm{Nper}}\right|=0.3\right)>\mathrm{MR}>\mathrm{dc}>\mathrm{Vc}>\mathrm{ac}>$ $\left(\left|\mathrm{k}_{\mathrm{Nper}}\right|=0.2\right)$, thus at the most of the critical properties of octanes.

The contribution of $\mathrm{N}_{\mathrm{asym} \perp}$ is higher than the contribution of other structural features at $\mathrm{B}>$ Sol. par. $>$ CED, all $\left(\left|\mathrm{k}_{\mathrm{Nasym} \perp}\right| \sim 0.3\right)$.

The contribution of $\mathrm{N}_{\mathrm{d}}$ is higher than the contribution of other structural features at $\operatorname{logVP}$ only.

The $\mathrm{MOC}_{\mathrm{SN}}$ was optimized also to some well-known topological indices of octanes in order to see the situation among them. The results are presented in Table 4.

The optimized $\mathrm{MOC}_{\mathrm{SN}}$ represents $88.2 \%$ of the information regarding branching of octanes contained in the Branching degrees ${ }^{13}$ derived from the values of index $\mathrm{V}_{\mathrm{L}}(-$ $0.126,-0.139,-0.270)$. It represents $87.9 \%$ of the information regarding branching of octanes contained in the Wiener ${ }^{1}$ index W, whereas it represents only $50.8 \%$ of the information regarding branching of octanes contained in the index $\mathrm{p} 4$.

\section{Discussion}

Interestingly, the best correlation to the individually optimized $\mathrm{MOC}_{\mathrm{SN}}$ has the physicochemical property $\mathrm{Tc} / \mathrm{Pc}(R=0.9939, I C=89.0 \%)$, closely followed by the Branching Degrees ${ }^{13}$ derived from the values of the index $\mathrm{V}_{\mathrm{L}}(-0.126,-0.139,-0.270)(R=0.9930, I C=88.2 \%)$, the Wiener ${ }^{1}$ index W $(R=0.9926, I C=87.9 \%)$, the index ${ }^{16}$ RW $(R=0.9924, I C=87.7 \%)$, and index ${ }^{18} \mathrm{p} 2 / \mathrm{w} 2(R=$ $0.9910, I C=86.6 \%)$, whereas the Randić ${ }^{17}$ index $\chi$ correlates to $R=0.9764, I C=78.4 \%$ and the Hosoya ${ }^{2}$ index $Z$ to $R=0.9755, I C=78.0 \%$. Among the path indices, ${ }^{18}$ the correlation to the individually optimized $\mathrm{MOC}_{\mathrm{SN}}$ is $\mathrm{p} 3>$ $\mathrm{p} 2>\mathrm{p} 5>\mathrm{p} 4$, and $\mathrm{p} 2 / \mathrm{w} 2>\mathrm{p} 3 / \mathrm{w} 3>\mathrm{p} 5 / \mathrm{w} 5>\mathrm{p} 4 / \mathrm{w} 4$ as well as $\mathrm{p} 2 / \mathrm{w} 2>\mathrm{p} 2, \mathrm{p} 3>\mathrm{p} 3 / \mathrm{w} 3, \mathrm{p} 4 / \mathrm{w} 4>\mathrm{p} 4, \mathrm{p} 5>\mathrm{p} 5 / \mathrm{w} 5$.
Whereas at $\mathrm{Tc} / \mathrm{Pc}$ the magnitude of the optimized factors $\left|\mathrm{k}_{\mathrm{Ni}}\right|$ is $\left|\mathrm{k}_{\mathrm{Nbr}}\right|>\left|\mathrm{k}_{\mathrm{Nper}}\right|>\left|\mathrm{k}_{\mathrm{Lbr}}\right|>\left|\mathrm{k}_{\mathrm{Nasym} \leftrightarrow}\right|>\left|\mathrm{k}_{\mathrm{Nasym} \perp}\right|$ $>\left|\mathrm{k}_{\mathrm{Nd}}\right|$, at $\mathrm{V}_{\mathrm{L}}(-0.126,-0.139,-0.270)$ it is $\left|\mathrm{k}_{\mathrm{Nbr}}\right|>\left|\mathrm{k}_{\mathrm{Nper}}\right|>$ $\left|\mathrm{k}_{\mathrm{Nasym} \leftrightarrow}\right|>\mathrm{k}_{\mathrm{Nd}}|>| \mathrm{k}_{\mathrm{Lbr}}|>| \mathrm{k}_{\mathrm{Nasym} \perp} \mid$, at W it is $\left|\mathrm{k}_{\mathrm{Nbr}}\right|>\left|\mathrm{k}_{\mathrm{Lbr}}\right|$ $\sim\left|\mathrm{k}_{\mathrm{Nper}}\right|>\left|\mathrm{k}_{\mathrm{Nasym} \perp}\right|>\left|\mathrm{k}_{\mathrm{Nasym} \leftrightarrow}\right|>\left|\mathrm{k}_{\mathrm{Nd}}\right|$, at RW it is $\left|\mathrm{k}_{\mathrm{Nbr}}\right|>$ $\left|\mathrm{k}_{\mathrm{Npe}} \mathrm{r}\right|>\left|\mathrm{k}_{\mathrm{Lbr}}\right|>\mathrm{k}_{\mathrm{Nd}}|>| \mathrm{k}_{\mathrm{Nasym} \perp}|>| \mathrm{k}_{\mathrm{Nasym} \leftrightarrow} \mid$, at the Randić ${ }^{17}$ index $\chi$ it is $\left|\mathrm{k}_{\mathrm{Nbr}}\right|>\left|\mathrm{k}_{\mathrm{Lbr}}\right| \sim\left|\mathrm{k}_{\mathrm{Nper}}\right|>\left|\mathrm{k}_{\mathrm{Nd}}\right|>\left|\mathrm{k}_{\mathrm{Nasym} \perp}\right|>$ $\left|\mathrm{k}_{\mathrm{Nasym} \leftrightarrow} \leftrightarrow\right|$ and at the Hosoya ${ }^{2}$ index $\mathrm{Z}$ it is $\left|\mathrm{k}_{\mathrm{Nbr}}\right|>\left|\mathrm{k}_{\mathrm{Lbr}}\right|>$ $\left|\mathrm{k}_{\mathrm{Nper}}\right||>| \mathrm{k}_{\mathrm{Nasym} \perp}|>| \mathrm{k}_{\mathrm{Nd}}>\left|\mathrm{k}_{\mathrm{Nasym} \leftrightarrow}\right|$.

Information contribution of the Structural Numbers $\mathrm{N}_{\mathrm{br}}, \mathrm{N}_{\text {per }}, \mathrm{N}_{\mathrm{d}}, \mathrm{L}_{\mathrm{br}}, \mathrm{N}_{\mathrm{asym} \leftrightarrow} \leftrightarrow$ and $\mathrm{N}_{\mathrm{asym} \perp}$ to the values of physicochemical properties of octanes as measured by the product $I C \times\left|\mathrm{k}_{\mathrm{Ni}}\right|(\%)$ is presented in Table 4 and illustrated in Figure 1.

In Table 4 and Figure 1 we can see that in the case of octanes the highest observed contributions of tested Structural Numbers are as follows. The Number of Branches contributes up to $60.4 \%$ of the Information Content (the case of RON). The Peripheral Number contributes up to $24.1 \%$ of the Information Content (the case of surface tension). The Size of the Largest Branch contributes up to $20.8 \%$ of the Information Content (the case of MON). The Asymmetry Number $\mathrm{N}_{\text {asym } \perp}$ contributes up to $20.0 \%$ of the Information Content (the case of the Antoine constant B). The Asymmetry number $\mathrm{N}_{\text {asym } \leftrightarrow}$, on the other hand, contributes only up to $8.3 \%$ of the Information Content (the case of the Antoine constant $\mathrm{A}$ ). The maximum contributions are thus at $\mathrm{N}_{\mathrm{br}}>>\mathrm{N}_{\text {per }}>\mathrm{L}_{\mathrm{br}}>\mathrm{N}_{\text {asym } \perp}>\mathrm{N}_{\mathrm{d}}>\mathrm{N}_{\text {asym } \leftrightarrow \text {. }}$

The contributions in particular physicochemical properties are quite varying. The Number of Branches in octanes contributes the most to the values of physicochemical properties (in \%; total $I C=100 \%$ ): $61>\mathrm{RON}>\omega$ $>\mathrm{Tc}^{2} / \mathrm{Pc}>\mathrm{BON}>\mathrm{BP} / \mathrm{Tc}>50$, and the least to the values of physicochemical properties: $10>\mathrm{Zc}>a c>$ Surface Tension $>\log \mathrm{VP}>\mathrm{CED}>$ Sol. par. $>\mathrm{B}>0.5$. The Peripheral number contributes in general much less, the most to the values of physicochemical properties (in \%): $25>$ Surface Tension $>\mathrm{Tc}>\mathrm{Pc}>\mathrm{BP}>\mathrm{Tc} / \mathrm{Pc}>20$, and the least to the

Table 4. Results of optimization of the correlation between the $\mathrm{MOC}_{\mathrm{SN}}$ and the values of some topological indices of octanes. The values of topological indices of octanes were taken from Ref. $1,2,13,16-18$

\begin{tabular}{|c|c|c|c|c|c|c|c|c|c|}
\hline Index & $\mathbf{k}_{\mathrm{Nbr}}$ & $\mathbf{k}_{\text {Nper }}$ & $\mathbf{k}_{\mathrm{Nd}}$ & $\mathbf{k}_{\mathrm{Lbr}}$ & $\mathbf{k}_{\text {Nasim }} \leftrightarrow$ & $\mathbf{k}_{\text {Nasim } \perp}$ & $R$ & $S$ & IC (\%) \\
\hline Br. Deg. $V_{L}$ & 0.669 & -0.108 & -0.063 & 0.053 & 0.082 & 0.025 & 0.9930 & 0.062 & 88.2 \\
\hline $\mathrm{W}$ & -0.554 & 0.181 & 0.003 & -0.188 & 0.015 & -0.059 & 0.9926 & 0.808 & 87.9 \\
\hline RW & 0.634 & -0.163 & -0.053 & 0.085 & 0.021 & 0.044 & 0.9924 & 0.070 & 87.7 \\
\hline$\chi$ & -0.552 & -0.141 & 0.118 & 0.145 & 0.007 & 0.037 & 0.9764 & 0.037 & 78.4 \\
\hline $\mathrm{Z}$ & -0.459 & -0.152 & 0.075 & 0.190 & 0.032 & -0.092 & 0.9755 & 1.009 & 78.0 \\
\hline $\mathrm{p} 2$ & 0.689 & 0.005 & -0.154 & -0.102 & -0.015 & 0.035 & 0.9704 & 0.365 & 75.8 \\
\hline p3 & 0.321 & -0.273 & 0.015 & 0.194 & 0.082 & -0.115 & 0.9765 & 0.334 & 78.5 \\
\hline $\mathrm{p} 4$ & -0.363 & 0.083 & 0.168 & -0.030 & -0.060 & 0.296 & 0.8703 & 0.657 & 50.8 \\
\hline p5 & -0.471 & 0.326 & -0.021 & 0.021 & -0.030 & -0.131 & 0.9351 & 0.505 & 64.6 \\
\hline $\mathrm{p} 2 / \mathrm{w} 2$ & 0.781 & 0.012 & -0.098 & -0.066 & -0.008 & -0.035 & 0.9910 & 0.007 & 86.6 \\
\hline $\mathrm{p} 3 / \mathrm{w} 3$ & 0.232 & -0.284 & 0.035 & 0.231 & 0.095 & -0.123 & 0.9561 & 0.017 & 70.7 \\
\hline $\mathrm{p} 4 / \mathrm{w} 4$ & -0.356 & -0.093 & 0.172 & 0.175 & 0.015 & 0.189 & 0.9024 & 0.014 & 56.9 \\
\hline p5/w5 & -0.472 & 0.316 & -0.032 & 0.027 & -0.028 & -0.125 & 0.9287 & 0.008 & 62.9 \\
\hline
\end{tabular}


Table 4. Information contribution of the Structural Numbers $\mathrm{N}_{\mathrm{br}}, \mathrm{N}_{\text {per }} \mathrm{N}_{\mathrm{d}}, \mathrm{L}_{\mathrm{br}}, \mathrm{N}_{\mathrm{asym} \leftrightarrow}$, and $\mathrm{N}_{\text {asym } \perp}$ to the values of physicochemical properties of octanes as measured by the product $I C \times\left|\mathrm{k}_{\mathrm{Ni}}\right|(\%)$ and sorted by $I C$.

\begin{tabular}{|c|c|c|c|c|c|c|c|}
\hline РСP & $I C \times\left|\mathrm{k}_{\mathrm{Nbr}}\right|$ & $I C \times\left|\mathrm{k}_{\mathrm{Nper}}\right|$ & $I C \times\left|\mathrm{k}_{\mathrm{Nd}}\right|$ & $I C \times\left|\mathrm{k}_{\mathrm{Lbr}}\right|$ & $I C \times\left|\mathbf{k}_{\text {Nasym }} \leftrightarrow\right|$ & $I C \times\left|\mathbf{k}_{\text {Nasym } \perp}\right|$ & IC (\%) \\
\hline $\mathrm{Tc} / \mathrm{Pc}$ & 48.2 & 20.6 & 0.3 & 14.1 & 3.8 & 2.1 & 89.0 \\
\hline $\mathrm{Tc}^{2} / \mathrm{Pc}$ & 55.5 & 7.7 & 2.7 & 12.1 & 0.6 & 8.8 & 87.4 \\
\hline RON & 60.4 & 6.9 & 0.5 & 13.1 & 5.1 & 1.0 & 87.1 \\
\hline BON & 54.8 & 7.7 & 2.0 & 14.6 & 4.5 & 2.1 & 85.6 \\
\hline $\mathrm{BP} / \mathrm{Tc}$ & 50.0 & 16.9 & 5.5 & 6.9 & 2.3 & 2.3 & 83.9 \\
\hline Pc & 35.7 & 21.9 & 2.2 & 12.0 & 4.1 & 7.3 & 83.2 \\
\hline$\omega$ & 56.7 & 12.3 & 6.1 & 2.5 & 0.8 & 2.8 & 81.2 \\
\hline MON & 47.5 & 5.2 & 1.4 & 20.8 & 3.8 & 0.7 & 79.4 \\
\hline $\mathrm{d}$ & 22.3 & 18.7 & 3.2 & 14.1 & 3.9 & 11.0 & 73.2 \\
\hline $\mathrm{Vm}$ & 22.0 & 18.7 & 3.3 & 13.9 & 4.0 & 10.9 & 72.9 \\
\hline $\mathrm{n}_{\mathrm{D}}$ & 20.9 & 16.3 & 6.2 & 13.9 & 3.1 & 12.0 & 72.5 \\
\hline$\Delta \mathrm{Hv}$ & 35.9 & 6.1 & 2.4 & 8.8 & 1.7 & 15.9 & 70.9 \\
\hline BP & 16.9 & 21.5 & 0.8 & 7.7 & 6.1 & 17.5 & 70.5 \\
\hline ST & 8.0 & 24.1 & 4.4 & 14.0 & 3.2 & 16.7 & 70.4 \\
\hline $\mathrm{Tc}$ & 13.5 & 24.0 & 3.3 & 8.6 & 5.6 & 13.6 & 68.6 \\
\hline C & 41.6 & 1.2 & 12.3 & 2.3 & 8.1 & 2.9 & 68.4 \\
\hline S & 33.4 & 5.0 & 13.4 & 4.5 & 7.1 & 3.6 & 67.0 \\
\hline $\mathrm{R}^{2}$ & 33.8 & 4.8 & 8.4 & 14.6 & 1.3 & 3.0 & 65.9 \\
\hline CED & 4.7 & 16.3 & 6.5 & 16.6 & 2.2 & 19.6 & 65.8 \\
\hline Sol.par. & 4.7 & 16.2 & 6.4 & 16.6 & 2.2 & 19.6 & 65.7 \\
\hline B & 0.5 & 14.2 & 14.4 & 11.6 & 4.4 & 20.0 & 65.1 \\
\hline MR & 16.7 & 18.0 & 5.0 & 9.8 & 5.4 & 5.2 & 60.2 \\
\hline$\Delta \mathrm{Hf}^{\circ} \mathrm{g}$ & 11.2 & 19.7 & 8.5 & 6.2 & 7.1 & 4.8 & 57.6 \\
\hline A & 14.9 & 5.8 & 10.8 & 6.9 & 8.3 & 10.6 & 57.2 \\
\hline $\log V P$ & 7.5 & 5.4 & 13.9 & 9.1 & 6.1 & 11.3 & 53.3 \\
\hline Vc & 12.7 & 13.7 & 4.1 & 7.6 & 7.7 & 2.5 & 48.2 \\
\hline $\mathrm{dc}$ & 12.2 & 13.4 & 4.0 & 7.1 & 7.6 & 2.4 & 46.7 \\
\hline $\mathrm{Zc}$ & 9.3 & 6.8 & 6.1 & 1.8 & 7.3 & 4.7 & 36.2 \\
\hline$a c$ & 8.3 & 8.6 & 7.5 & 1.9 & 6.3 & 1.6 & 34.3 \\
\hline
\end{tabular}

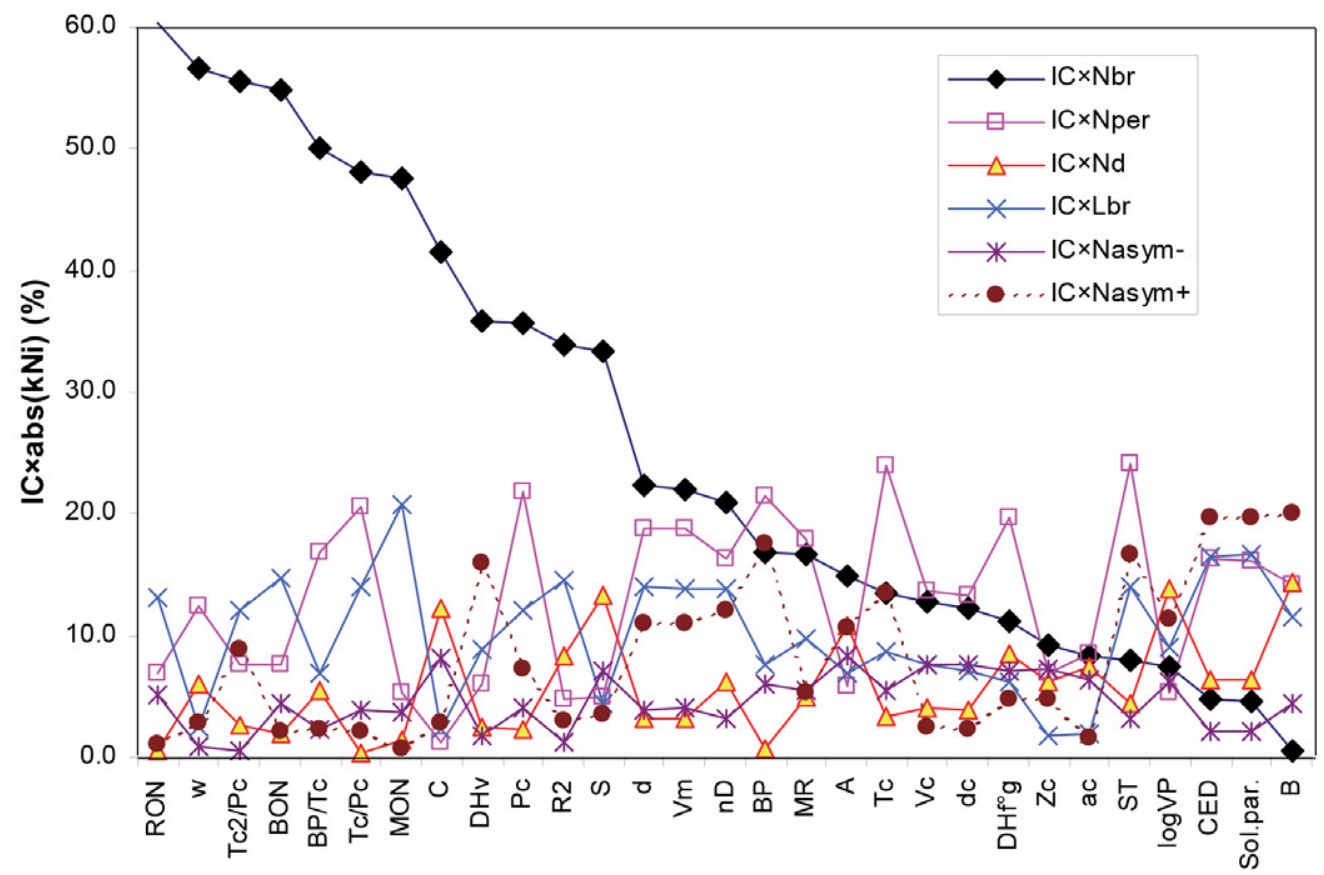

Figure 1. Information contribution of the Structural Numbers $\mathrm{N}_{\mathrm{br}} \mathrm{N}_{\text {per }}, \mathrm{N}_{\mathrm{d}}, \mathrm{L}_{\mathrm{br}}, \mathrm{N}_{\mathrm{asym} \leftrightarrow}$, and $\mathrm{N}_{\text {asym } \perp}$ about the values of physicochemical properties of octanes as measured by the product $I C \times\left|\mathrm{k}_{\mathrm{Ni}}\right|(\%)$ and sorted by the contribution of the Number of Branches. 
values of physicochemical properties: $6>\mathrm{A}>\log \mathrm{VP}>$ $\mathrm{MON}>\mathrm{S}>\mathrm{R}^{2}>\mathrm{C}>1$. The Distance number contributes less, the most to the values of physicochemical properties (in \%): $15>\mathrm{B}>\operatorname{logVP}>\mathrm{S}>\mathrm{C}>\mathrm{A}>10$, and the least to the values of physicochemical properties: $2>\mathrm{BON}>\mathrm{MON}>$ $\mathrm{BP}>\mathrm{RON}>\mathrm{Tc} / \mathrm{Pc}>0.1$.

The Size of the Largest Branch contributes the most to the values of physicochemical properties (in \%): $21>$ MON $>$ Sol. par. $>$ CED $>15$, and the least to the values of physicochemical properties: $7>\mathrm{BP} / \mathrm{Tc}>\mathrm{A}>\Delta \mathrm{Hf}^{\circ} \mathrm{g}>\mathrm{S}>$ $\omega>\mathrm{C}>\mathrm{ac}>\mathrm{Zc}>1$.

The Asymmetry number $\mathrm{N}_{\text {asym } \leftrightarrow}$ contributes the most to the values of physicochemical properties (in \%): $9>\mathrm{A}>\mathrm{C}>\mathrm{Vc}>\mathrm{dc}>\mathrm{Zc}>\Delta \mathrm{Hf}^{\circ} \mathrm{g}>\mathrm{S}>7$, and the least to the values of physicochemical properties: $3>\mathrm{BP} / \mathrm{Tc}>\mathrm{CED}$ $>$ Sol. par. $>\Delta \mathrm{Hv}>\mathrm{R}^{2}>\omega>\mathrm{Tc}^{2} / \mathrm{Pc}>0.5$.

The Asymmetry number $\mathrm{N}_{\text {asym } \perp}$ contributes the most to the values of physicochemical properties (in \%): $20>\mathrm{B}>$ Sol. par. $>\mathrm{CED}>\mathrm{BP}>$ Surface Tension $>\Delta \mathrm{Hv}>15$, and the least to the values of physicochemical properties: $2.5>\mathrm{Vc}>$ $\mathrm{dc}>\mathrm{BP} / \mathrm{Tc}>\mathrm{Tc} / \mathrm{Pc}>\mathrm{BON}>\mathrm{ac}>\mathrm{RON}>\mathrm{MON}>0.5$.

In most cases (with exception of $\mathrm{Tc} / \mathrm{Pc}, \mathrm{Tc}^{2} / \mathrm{Pc}$, and $\mathrm{RON}$ ) the structural numbers in form of the optimized $\mathrm{MOC}_{\mathrm{SN}}$ do not suffice the criterion that for a useful correlation, $R>0.99$ must be obtained. ${ }^{19}$

To obtain better correlations, the mutually optimized combinations of vertex-degree vertex-distance weighted elements of the Universal matrix and vertex-degree weighted path indices are to be used. ${ }^{15,20-22}$
As shown above, the values of the mutually optimized factors $\mathrm{k}_{\mathrm{Ni}}$ as well as of products $I C \times\left|\mathrm{k}_{\mathrm{Ni}}\right|$ are useful for the structural interpretation of the values of physicochemical properties of octanes, as well. Whereas in the best case, i.e. at $\mathrm{Tc} / \mathrm{Pc}$ there they explain $89.0 \%$ of the information regarding branching of octanes $(48.2 \%$ is explained by $\mathrm{N}_{\text {br }}, 20.6 \%$ by $\mathrm{N}_{\text {per }}, 14.1 \%$ by $\mathrm{L}_{\text {br }}, 3.8 \%$ by $\mathrm{N}_{\text {asym } \leftrightarrow}, 2.1 \%$ by $\mathrm{N}_{\text {asym } \perp}$, and only $0.3 \%$ by $\mathrm{N}_{\mathrm{d}}$ ), in the worst observed case, i.e. at the critical property ac there is explained only $34.3 \%$ of the information regarding branching of octanes (8.6\% is explained by $\mathrm{N}_{\text {per }}, 8.3 \%$ by $\mathrm{N}_{\text {br }}, 7.5 \%$ by $\mathrm{N}_{\mathrm{d}}, 6.3 \%$ by $\mathrm{N}_{\text {asym } \leftrightarrow,} 1.9 \%$ by $\mathrm{L}_{\text {br }}$ and $1.6 \%$ by $\mathrm{N}_{\text {asym } \perp}$ ).

The mutually optimized factors $\mathrm{k}_{\mathrm{Ni}}$ as well as the products $I C \times\left|\mathrm{k}_{\mathrm{Ni}}\right|$ contribute thus to the structural interpretation of the values of physicochemical properties of octanes to different extents at different physicochemical properties of octanes. After determining their contribution, in most cases additional factors are to be sought for.

The situation for physicochemical properties of octanes $\mathrm{Tc} / \mathrm{Pc}, \mathrm{d}, \mathrm{MR}, \mathrm{dc}$, and $\mathrm{Tc}$ is illustrated in Figure 2. It is presented as the difference between the experimental values of the physicochemical properties of octanes and the values calculated using mutually optimized contribution of all the tested Structural features reduced by the average of the experimental values of physicochemical properties of octanes.

In the case of $\mathrm{Tc} / \mathrm{Pc}$, for example, where $I C=89.0 \%$, there remains open the question why at the octane isomers 3M7, 3Et6, 24M6, 3Et2M5, 22M6, 234M5, and 2233M4 the calculated values almost fit the experimental ones,

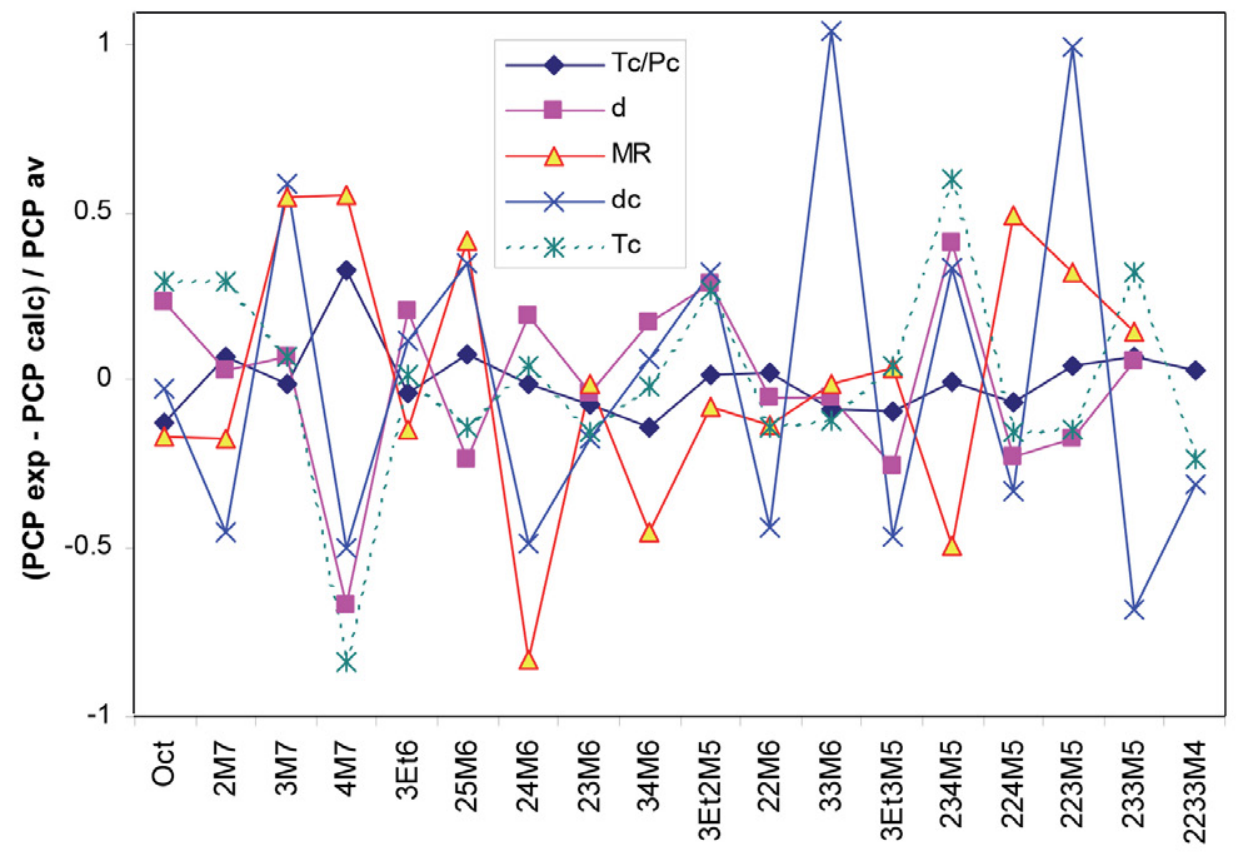

Figure 2. Reduced differences between the experimental values of the physicochemical properties of octanes and the values calculated using mutually optimized contribution of all the tested Structural features. 
whereas at 4M7, 25M6, 233M5 the experimental values are higher than the calculated ones, and at Oct, 34M6, 33M6, 3Et3M5, and 224M5 they are lower.

Another example is e.g. dc, where $I C=46.7 \%$. There remains open the question why at the octane isomers the calculated values almost fit the experimental ones only at Oct and 34M6, whereas at 3M7, 25M6, 2Et3M5, and especially at $33 \mathrm{M} 6$ and $223 \mathrm{M} 5$ the experimental values are higher than the calculated ones, and at 2M7, 4M7, 24M6, 22M6, 3Et3M5, 224M5, and 233M5 they are lower. This situation calls for additional study.

\section{References}

1. H. Wiener, J. Am. Chem. Soc. 1947, 69, 17-20. DOI:10.1021/ja01193a005

2. H. Hosoya, Bull. Chem. Soc. Jpn. 1971, 44, 2332-2339. DOI:10.1246/bcsj. 44.2332

3. H. Hosoya, Internet Electron. J. Mol. Des. 2002, 1, 428-442.

4. E. C. Kirby, J. Chem. Inf. Comput. Sci. 1994, 34, 1030-1035. DOI:10.1021/ci00021a001

5. D. H. Rouvray, J. Comput. Chem. 1987, 8, 470-480.

DOI:10.1002/jcc.540080427

6. D. Bonchev, N. Trinajstić, J. Chem. Phys. 1977, 67, 4517-4533. DOI:10.1063/1.434593

7. D. Bonchev, J. Mol. Struct. (Theochem) 1995, 336, 137-156. DOI:10.1063/1.434593
8. M. Randić, Acta Chim. Slov. 1997, 44, 57-77.

9. L. Lovasz, J. Pelikan, Period Math Hung. 1973, 3, 175-182. DOI:10.1007/BF02018473

10. D. M. Cvetković, I. Gutman, Croat. Chem. Acta 1977, 49, 115-121.

11. M. Randić, C. L. Wilkins, J. Phys. Chem. 1979, 83, 1525-1540. DOI:10.1021/j100474a032

12. A. Perdih, Indian J. Chem. 2003, 42A, 1246-1257.

13. A. Perdih, Acta Chim. Slov. 2016, 63, 411-415. DOI:10.17344/acsi.2015.1607

14. A. Perdih, M. Perdih, Acta Chim. Slov. 2000, 47, 231-259. DOI:10.17344/acsi.2015.1607

15. A. Perdih, Acta Chim. Slov. 2015, 62, 879-888. DOI:10.17344/acsi.2015.1607

16. M.V. Diudea, J. Chem. Inf. Comput. Sci. 1997, 37, 292-299. DOI:10.1021/ci960037w

17. M. Randić, J. Am. Chem. Soc. 1975, 97, 6609-6615. DOI:10.1021/ja00856a001

18. M. Randić, J. Chem. Inf. Comput. Sci. 2001, 41, 607-613. DOI: $10.1021 / \mathrm{ci} 0001031$

19. Z. Mihalić, N. Trinajstić, J. Chem. Educ. 1992, 69, 701-712. DOI:10.1021/ed069p701

20. A. Perdih, Acta Chim. Slov. 2016, 63, 88-96. DOI:10.17344/acsi.2015.1975

21. A. Perdih, Acta Chim. Slov. 2016, 63, 411-415. DOI:10.17344/acsi.2016.2361

22. A. Perdih, Acta Chim. Slov. 2019, 66, 726-731. DOI:10.17344/acsi.2019.5346

\section{Povzetek}

S strukturnimi števili so bile kvantificirane strukturne značilnosti izomer oktana. Za ugotovitev, kolikšen del vsebine podatkov o fizikokemijskih lastnosti oktanov nam dajejo strukturna števila, je bil razvit način, kako določiti hkratno optimiziran doprinos strukturnih števil $\left(\mathrm{MOC}_{\mathrm{SN}}\right)$. Poleg drugih strukturnih števil predstavljenih prej, sta uvedeni še števili, ki predstavljata merili za nesimetričnost izomer oktana. Eno predstavlja nesimetričnost vzdolž glavne osi molekule, drugo pa nesimetričnost pravokotno nanjo. Njuni korelaciji z vrednostmi 29 fizikokemijskih lastnosti oktanov sta nizki, $|R|<0.6$. Po optimizaciji vsebuje $\mathrm{MOC}_{\mathrm{SN}}$ od $34.3 \%$ do $89.0 \%$ informacije vsebovane v fizikokemijskih lastnostih oktanov. Strukturna števila omogočajo prvi korak k strukturni razlagi fizikokemijskih lastnosti oktanov. V 17 od 29 primerov največ informacij poda število vej, v 8 primerih periferno število, v 3 primerih eno od števil nesimetričnosti in $\mathrm{v}$ enem primeru število razdalj med vejami.

Except when otherwise noted, articles in this journal are published under the terms and conditions of the Creative Commons Attribution 4.0 International License 